\title{
PROSTOČASNA POTOVANJA IN SLOVENSKO PREBIVALSTVO
}

Dejan Cigale: Prostočasna potovanja in slovensko prebivalstvo. Zbirka E-GeograFF 8. Znanstvena založba Filozofske fakultete Univerze $\mathbf{v}$ Ljubljani in Oddelek za geografijo, 106 str. Ljubljana, 2015

Avtor monografije se je lotil zanimive tematike prostega časa kot fenomena 20. st., njegovega preživljanja in najrazličnejših ekonomskih, okoljskih in tudi širših družbenih učinkov. Njen osrednji del je analiza rezul-

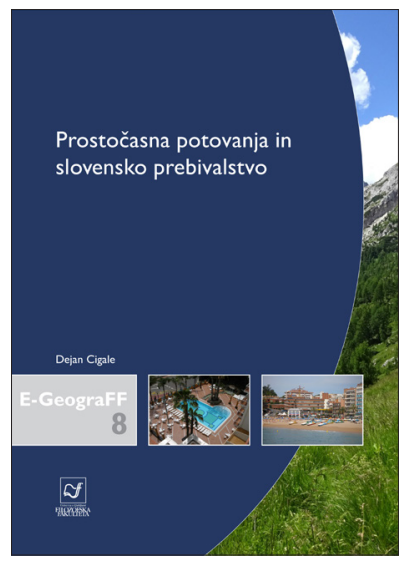
tatov dveh obsežnejših raziskav, s katerima je poskušal ugotoviti, kako in kje slovensko prebivalstvo preživlja svoj prosti čas. Prva se ukvarja z zasebnimi turističnimi potovanji (brez poslovnih in drugih službenih potovanj) in izhaja iz podatkov za leto 2013, ki jih je zbiral Statistični urad Republike Slovenije. V drugi raziskavi se je avtor lotil obravnave kratkotrajnejših potovanj (izletov), ki niso navezana na »na razmeroma redke dogodke, kakršne so počitnice, zato predstavlja [jo] za številne posameznike del rednega, običajnega prostočasnega ravnanja.«. Podatke za analizo je zbiral s pomočjo dveh anket; s prvo $(\mathrm{N}=1459)$ je poleg osnovnih značilnosti tovrstnih potovanj ugotavljal predvsem dejavnike, ki vplivajo na izbiro ciljev in kakovostnega preživljanja prostega časa, z drugo $(\mathrm{N}=362)$ pa je poskušal rezultate postaviti v širši družbeni kontekst in ugotoviti, kakšen pomen nasploh pripisujejo posamezniki prostemu času. Primerjava dobljenih rezultatov z ugotovitvami desetletje in več starimi preučevanji je pokazala zanimive razlike, te pa je avtor v nadaljevanju tudi izčrpno pojasnil v širšem, geografskem kontekstu, ki daleč presega zgolj ekonomski vidik turizma.

Monografija je razdeljena na devet poglavij in vrsto podpoglavij, iz katerih je razmeroma dobro razvidna rdeča nit avtorjevega razmišljanja, ni pa branje posebej 'lahkotno'. $\mathrm{V}$ delu se namreč tesno prepletata dva načina preživljanja prostega časa (počitniška in druga daljša potovanja ter izletništvo), ki jih je takorekoč nemogoče povsem ločiti, ter dejavniki privlačnosti in odvračanja (avtor jih imenuje 'moteči dejavniki' oziroma 'moteče značilnosti izletniškega območja'). Nekateri od teh dejavnikov so povezani z značilnostmi ciljnih območij, drugi z družbenim statusom in ostalimi značilnostmi posameznika, obenem pa se je moral avtor še precej ubadati s terminološkimi zagatami.

V prvem delu monografije, ki se ukvarja z zasebnimi turističnimi potovanji, so poleg nekaterih splošno poznanih ugotovitev (npr. Hrvaška kot glavni cilj tovrstnih potovanj, večji delež potovanj med mlajšo generacijo kot med upokojenci), prav tako zanimivi trendi v skupini, ki ni bila v letih 2012 in 2013 na nobenem takšnem potovanju in bi jih bilo morda koristno še natančneje analizirati: povečal se je npr. delež ljudi, ki ni potoval 
iz finančnih razlogov (2012: 49,0 \%; 2013: 54,4 \%), in tistih, ki ne čutijo nobene potrebe po potovanju (s 15,6 na $16,4 \%$ ).

Drugi del monografije je še zanimivejši, saj obravnava bolj vsakdanji del preživljanja prostega časa, ki ni vezan na čas dopustov in za katerega so poleg rekreacijskih aktivnosti značilni predvsem enodnevni izleti. Ta del našega vsakdana je po mnenju avtorja tesno povezan s socialnimi in demogeografskimi značilnostmi posameznikov ter njihovimi rekreacijskimi navadami. Prav tako se v tem kažejo zanimive posebnosti naše družbe, npr. izrazita prevlada osebnega avtomobila (uporablja ga kar 84,4 \% anketirancev, v veliki meri zaradi slabo urejenega javnega potniškega prometa), precejšnja priljubljenost kolesa (14,7 \% anketirancev), zelo majhen delež izletnikov 'samotarjev' $(9,9 \%)$ in izrazita prevlada enodnevnih izletnikov (86,2\%).

Zelo zanimive so tudi ugotovitve o dejavnikih, ki vplivajo na izbiro izletniškega cilja, a je v takšni študiji nemogoče zajeti celotno paleto teh dejavnikov, tudi socioloških, psiholoških in drugih negeografskih nagibov. Avtorjeva analiza rezultatov anketiranja nakazuje čisto nove geografske izzive in ponuja obilo gradiva za geografovo razmišljanje o zapletenih odnosih med človekom in okoljem, npr. kaj si ljudje predstavljamo pod pojmoma 'privlačna pokrajina' ali 'čisto okolje', ki sta po mnenju anketirancev daleč najpomembnejša dejavnika pri izbiri izletniškega cilja.

Predstavljeno delo D. Cigaleta je lepo napisana in urejena geografska monografija, ki ponuja zanimivo branje tudi nestrokovnjaku, predvsem pa jo lahko ocenjujemo kot pomemben prispevek k širšemu razumevanju zelo zapletenega pojava preživljanja prostega časa. Morda se v eni od iztočnic, da turizma in prostočasnih dejavnosti ne smemo obravnavati zgolj z ekonomskega vidika, čeprav sta nesporno pomembni gospodarski dejavnosti, nakazujejo tudi namigi, kako bi lahko s širšim pogledom na ta del družbenega delovanja dvignili kakovost preživljanja prostega časa in hkrati dosegli boljše ekonomske učinke. Monografija je v celoti dostopna bralcem na spletni strani Oddelka za geografijo Filozofske fakultete: http://geo.ff.uni-lj.si/sites/default/files/egeograff_8_prostocasna_potovanja_0.pdf.

\section{Karel Natek}

